\title{
Efficient Callus Induction through Anther Culture in Cultivars of Brassica campestris var. Brown Sarson
}

\author{
Sheetal Sood* and Vedna Kumari \\ Department of Crop Improvement, CSK HP KV Palampur, Himachal Pradesh-176061, India \\ *Corresponding author
}

\section{A B S T R A C T}

\begin{tabular}{|c|c|}
\hline & \\
\hline $\begin{array}{l}\text { Brassica } \\
\text { campestris, Callus, } \\
\text { Hormones, Media, } \\
\text { Anther culture }\end{array}$ & $\begin{array}{l}\text { campestris, namely HPBS-1, KBS-3, HPKM-04-1, HPBS- } 1 \text { x HPKM- } 04-1 \text { and KBS-3 x } \\
\text { HPKM-04-1 were cultured in vitro to observe their callus induction frequency. The effect } \\
\text { of two basal media i.e. MS and N6, two different sucrose concentrations i.e. } 3 \% \text { and } 4 \% \text {, } \\
\text { three combinations of growth hormones viz. HM1, HM2, HM3 and their callus induction }\end{array}$ \\
\hline Article Info & \\
\hline $\begin{array}{l}\text { Accepted: } \\
10 \text { April } 2019 \\
\text { Available Online: } \\
10 \text { May } 2019\end{array}$ & $\begin{array}{l}\text { NAA] and } 3 \text { per cent sucrose for callus induction frequency. This media and hormonal } \\
\text { combination can be successfully utilized for induction of haploids and double haploids in } \\
\text { future. }\end{array}$ \\
\hline
\end{tabular}

\section{Introduction}

Oilseed crops occupy an important place in world's economy. The cultivation of oilseeds (Brassica sp.) has increased tremendously from last few years and occupies a prominent position in daily diet, being a rich source of fats and vitamins. Brassica napus, Brassica juncea and Brassica campestris constitute the important source of edible oils (Gupta and Partap, 2007). Among oilseeds, rapeseedmustard contributes $28.6 \%$ in the total oilseeds production and ranks second after groundnut sharing $27.8 \%$ in the India's oilseed economy (Shekhawat et al., 2014).

Conventional methods for breeding crop plants require more than six to seven years of continuous efforts to get true breeding lines after following hybridization approach. However, the anther culture technique holds a great promise in accelerating the pace of breeding programme (Guha and Maheshwari, 1964). This system provides an unparallel opportunity to shorten the breeding cycle and fix agronomic traits in homozygous state instantly. The information pertaining to these parameters in brown sarson is limited.

Therefore, to harvest the multifarious merits of anther culture, the present research work was planned and carried out. Main objectives were establishment of a suitable and reproducible protocol for in vitro regeneration of callus through anther culture, optimization of the suitable combination and concentration 
of hormones on selected media for regeneration of Brassica genotypes.

\section{Materials and Methods}

The experiment was carried out in the Molecular Cytogenetics and Tissue culture Laboratory of Department of Crop Improvement, CSK HPKV, Palampur during rabi 2016-17. The material used for anther studies comprised of three elite genotypes and their cross combination (Table 1).

\section{Methods}

\section{Plant material for anther culture}

Sufficient numbers of plants of aforementioned three genotypes and their cross combinations were raised in the pots. In order to have availability of anthers over a long period of time, plants were raised in five lots at an interval of 15 days each.

\section{Media used for anther culture}

Two basal media viz., MS (Murashige and Skoog, 1962) and $\mathrm{N}_{6}$ (Chu, 1978) were used for callus induction. Each of these medium was supplemented with two different sucrose concentrations i.e. 3 per cent and 4 per cent sucrose and each of these sucrose concentrated media was also supplemented with three combinations of hormones viz., $\mathrm{HM}_{1}, \mathrm{HM}_{2}$ and $\mathrm{HM}_{3}$ (Table 2). All the media were supplemented with 0.8 per cent agar based upon the earlier studies (Kumari, 2010).

\section{Anther culture technique}

For anther culture, florets from plants were clipped off when the size of bud was about 2$4 \mathrm{~mm}$. The bud size was earlier established on the basis of presence of majority of the microspores at late uninoculate to early binucleate stage as studied by squashing of anthers in a drop of 1 per cent acetocarmine. The florets of appropriate size were collected in $50 \mathrm{ml}$ test tubes containing distilled water.

The florets collected at aforementioned stages were treated with 70 per cent ethanol for 1015 seconds under aseptic conditions in a laminar air flow chamber. The florets were then surface sterilized with 0.1 per cent $\mathrm{HgCl}_{2}$ for 3-5 minutes with intermittent shaking followed by three washings with sterile distilled water. Florets were blot dried and opened under aseptic conditions with the help of sterile forceps and the six anthers were clipped off from each floret without damaging the anther wall. About 60 anthers were cultured in each pre-sterilized petri plate containing about $25 \mathrm{ml}$ of culture medium. The experiments on different callus induction media were replicated thrice involving different media, sucrose concentrations and plant growth hormones. Anthers of all three genotypes and their crosses were plated in a replicated fashion. All the cultured plates were sealed with parafilm wax and kept under dark at $25 \pm 1{ }^{\circ} \mathrm{C}$ until calli were developed.

\section{Data analysis}

The experimental data was analysed in Factorial Completely Randomized Design (CRD) using statistical CPCS software to determine the effect of various genotypes, hormones, media, sucrose and their interactions on callus induction frequency.

\section{Statistical analysis}

Callus induction frequency (\%) was calculated as follows:

Callus induction frequency $(\%)=$

Number of calli forming anthers

Number of anthers plated 


\section{Results and Discussion}

Analysis of variance for callus induction frequency in anthers cultured in vitro on two media supplemented with two different sucrose concentrations and each of these sucrose concentrated media supplemented with three combinations of hormones is presented in Table 3. All four factors viz., genotypes, hormones, media and sucrose had significant effect on callus induction frequency. Eight out of eleven interactions viz., hormones $\mathrm{x}$ genotypes, media $\mathrm{x}$ genotypes, hormones $\mathrm{x}$ media, hormones $\mathrm{x}$ genotypes $\mathrm{x}$ media, sucrose $\mathrm{x}$ hormones $\mathrm{x}$ genotypes, media $\mathrm{x}$ sucrose, media $\mathrm{x}$ sucrose $\mathrm{x}$ genotypes and hormones $\mathrm{x}$ genotypes $\mathrm{x}$ media $x$ sucrose showed significant effect on callus induction frequency. The results are in conformity with the findings of Singh (2006), Kumari (2010) and Philem and Chadha (2010) in respect of media, hormones and hormones x media in Brassica species.

\section{Response of different genotypes on different media}

The experiment conducted to study the response of different genotypes on different media indicated that $\mathrm{N}_{6}$ gave highest callus induction frequency (68.42 \%) and was found significantly superior than MS medium. Out of the five genotypes used for anther culture, HPBS-1 gave highest mean callusing (70.85 $\%)$.

In interaction between media $x$ genotypes, the highest callus induction frequency was observed in KBS-3 x HPKM-04-1 (78.95 \%) on $\mathrm{N}_{6}$ medium followed by HPBS-1 (71.87 $\%)$ in MS medium and HPKM-04-1 (70.90 $\%$ ) on $\mathrm{N}_{6}$ medium. Overall it was observed that $\mathrm{N}_{6}$ medium was best for callus induction frequency as indicated in Table 4 \& Figure 1. The differential response of different genotypes for days to callus induction were also reported by Alam et al., (2009), Khan et al., (2009) and Sayem et al., (2010) in Brassica species.

\section{Response of genotypes on different} hormones and their combination

It was revealed that callus induction differs from genotype to genotype as indicated in Table 5. Out of the five genotypes, HPBS-1 gave significantly highest callus induction frequency $(70.85 \%)$ followed by KBS-3 x HPKM-04-1 (70.44 \%) and HPKM-04-1 (69.17 \%) while HPBS-1 x HPKM-04-1 exhibited lowest callus induction frequency $(60.71 \%)$. Out of the three hormonal combinations tested, $\mathrm{HM}_{2}$ gave the highest mean callusing (70.71 \%). Overall, the genotype HPBS-1 and hormone $\mathrm{HM}_{2}$ [2,4$\mathrm{D}(0.5 \mathrm{mg} / \mathrm{l})+\mathrm{NAA}(1.0 \mathrm{mg} / \mathrm{l})]$ appeared to be best for callus induction frequency as indicated in Figure 2. Higher percentage of callus induction was observed on a medium with 2 mg/l 2, 4-D and NAA each by Roy and Saha (1997). The result is in consonance with the results of Kumari (2010) and Lone et al., (2017).

\section{Response of genotypes on different sucrose concentrations}

The experiment conducted to study the effect of sucrose and genotypes on callus induction frequency is presented in Table 6. Out of two different sucrose concentrations, 3 per cent sucrose gave significantly highest callus induction frequency $(68.33 \%)$ as indicated in Figure 3. Among five genotypes, HPBS-1 performed best with callus induction frequency $(70.85 \%)$ followed by KBS-3 x HPKM-04-1 (70.44 \%), both were found to be statistically at par with each other. Shitole (2012) reported that the concentration of 3\% sucrose would be adequate for callus induction in Ethopian mustard. 
Effects of sucrose and hormones on callus induction frequency

The perusal of data presented in Table 7 indicated that out of two different sucrose concentrations, 3 per cent sucrose showed highest callus induction frequency $(68.33 \%)$ and was found significantly superior than the 4 per cent sucrose concentration. Out of the three hormonal combinations, $\mathrm{HM}_{2}$ [2, 4-D $(0.5 \mathrm{mg} / \mathrm{l})+\mathrm{NAA}(1.0 \mathrm{mg} / \mathrm{l})]$ gave significantly highest callus induction frequency $(70.71 \%)$ than $\mathrm{HM}_{1}$ and $\mathrm{HM}_{3}$. Similar findings were also observed by Trivedi and Dubey (2014) and Ullah et al., (2004) in Brassica species.

Performance of media with different concentrations of hormones for callus induction frequency

The effect of hormones and media to culture of brassica anther undergoing in-vitro callusing was investigated. Among three hormonal combinations, $\mathrm{HM}_{2}(0.5 \mathrm{mg} / 1$ 2,4-D $+1.0 \mathrm{mg} / \mathrm{l}$ NAA) showed highest callus induction frequency to $(70.71 \%)$ and was found to be significantly superior than $\mathrm{HM}_{3}$ and $\mathrm{HM}_{1}$. It was observed that $\mathrm{N}_{6}$ medium showed highest callus induction $(68.42 \%)$ and was found to be significantly superior to the MS medium. The interaction between two factors i.e. hormones $\mathrm{x}$ media had significant effect on the callus induction frequency. Overall it was revealed that the highest callus induction frequency was observed in $\mathrm{N}_{6}$ medium supplemented with $\mathrm{HM}_{2}(72.86 \%)$ (Table 8). Roy and Saha (1997) reported higher per centage of callus induction frequency on $\mathrm{B}_{5}$ medium supplemented with $2 \mathrm{mg} / \mathrm{l}$ 2, 4-D and NAA (Table 8). Philem and Chadha (2010) also reported highest callus induction frequency in $\mathrm{B}_{5}$ medium $(24.94 \%)$ when supplemented with $\mathrm{HM}_{2}(0.5 \mathrm{mg} / \mathrm{l} 2$, 4$\mathrm{D}+1.0 \mathrm{mg} / \mathrm{l} \mathrm{NAA})$.

Performance of media with different sucrose concentrations for callus induction frequency

It was observed that the callus induction frequency was greatly influenced by media used for callus induction with the best results $(68.42 \%)$ achieved using $\mathrm{N}_{6}$ medium supplemented with $\mathrm{HM}_{2}$ [2,4-D $(0.5 \mathrm{mg} / \mathrm{l})$ +NAA (1mg/l)] Table 9. Shitole (2012) also observed 3 per cent sucrose concentration was for high callus induction frequency which is in confirmation with the results of present study.

Table.1 List of genotypes and their cross combinations used for anther culture study

\begin{tabular}{|c|l|l|}
\hline Sr. No & Genotype & \multicolumn{1}{|c|}{ Salient features } \\
\hline $\mathbf{1}$ & HPBS-1 & $\begin{array}{l}\text { High yielding, dwarf variety with short and } \\
\text { sturdy stem which makes it lodging resistant } \\
\text { and moderately resistant to Alternaria blight }\end{array}$ \\
\hline $\mathbf{2}$ & KBS-3 & High yielding variety with tolerant to frost \\
\hline $\mathbf{3}$ & HPKM-04-1 & Local collection from H.P. \\
\hline $\mathbf{4}$ & HPBS-1 x HPKM-04-1 & - \\
\hline $\mathbf{5}$ & KBS-3 $x$ HPKM-04-1 & - \\
\hline & & \\
\hline
\end{tabular}


Table.2 Different media, hormones and sucrose concentration used for callus induction

\begin{tabular}{|c|c|c|c|}
\hline Medium & $\begin{array}{c}\text { Sucrose } \\
\text { concentration }\end{array}$ & \multicolumn{2}{|c|}{ Hormone } \\
\cline { 3 - 4 } & $3 \%$ & Designation & Name and Concentration \\
\hline $\mathbf{M S}$ & $3 \%$ & $\mathrm{HM}_{1}$ & $2,4-\mathrm{D}(0.5 \mathrm{mg} / \mathrm{l})$ \\
\hline $\mathbf{M S}$ & $3 \%$ & $\mathrm{HM}_{2}$ & $2,4-\mathrm{D}(0.5 \mathrm{mg} / \mathrm{l})+\mathrm{NAA}(1.0 \mathrm{mg} / \mathrm{l})$ \\
\hline $\mathbf{M S}$ & $3 \%$ & $\mathrm{HM}_{3}$ & $\mathrm{NAA}(1.0 \mathrm{mg} / \mathrm{l})$ \\
\hline $\mathbf{M S}$ & $4 \%$ & $\mathrm{HM}_{1}$ & $2,4-\mathrm{D}(0.5 \mathrm{mg} / \mathrm{l})$ \\
\hline $\mathbf{M S}$ & $4 \%$ & $\mathrm{HM}_{2}$ & $2,4-\mathrm{D}(0.5 \mathrm{mg} / \mathrm{l})+\mathrm{NAA}(1.0 \mathrm{mg} / \mathrm{l})$ \\
\hline $\mathbf{M S}$ & $4 \%$ & $\mathrm{HM}_{3}$ & $\mathrm{NAA}(1.0 \mathrm{mg} / \mathrm{l})$ \\
\hline $\mathbf{N}_{\mathbf{6}}$ & $3 \%$ & $\mathrm{HM}_{1}$ & $2,4-\mathrm{D}(0.5 \mathrm{mg} / \mathrm{l})$ \\
\hline $\mathbf{N}_{\mathbf{6}}$ & $3 \%$ & $\mathrm{HM}_{2}$ & $2,4-\mathrm{D}(0.5 \mathrm{mg} / \mathrm{l})+\mathrm{NAA}(1.0 \mathrm{mg} / \mathrm{l})$ \\
\hline $\mathbf{N}_{\mathbf{6}}$ & $3 \%$ & $\mathrm{HM}_{3}$ & $\mathrm{NAA}(1.0 \mathrm{mg} / \mathrm{l})$ \\
\hline $\mathbf{N}_{\mathbf{6}}$ & $4 \%$ & $\mathrm{HM}_{1}$ & $2,4-\mathrm{D}(0.5 \mathrm{mg} / \mathrm{l})$ \\
\hline $\mathbf{N}_{\mathbf{6}}$ & $4 \%$ & $\mathrm{HM}_{2}$ & $2,4-\mathrm{D}(0.5 \mathrm{mg} / \mathrm{l})+\mathrm{NAA}(1.0 \mathrm{mg} / \mathrm{l})$ \\
\hline $\mathbf{N}_{\mathbf{6}}$ & $4 \%$ & $\mathrm{HM}_{3}$ & $\mathrm{NAA}(1.0 \mathrm{mg} / \mathrm{l})$ \\
\hline
\end{tabular}

Table.3 ANOVA for Callus induction frequency (\%) in different genotypes of Brassica campestris and their hybrids involving different media, hormones and sucrose concentration

\begin{tabular}{|l|l|l|l|l|}
\hline Source of variation & Df & $\begin{array}{l}\text { Mean } \\
\text { Squares }\end{array}$ & $\begin{array}{l}\text { CD } \\
\mathbf{( 5 \% )}\end{array}$ & $\begin{array}{l}\text { CV } \\
(\%)\end{array}$ \\
\hline Genotypes & 4 & $881.73^{*}$ & 4.09 & 13.3 \\
\hline Hormones & 2 & $1007.90^{*}$ & 3.17 \\
\hline Hormones x genotypes & 8 & $1198.79^{*}$ & 7.09 \\
\hline Media & 1 & $610.68^{*}$ & 2.59 \\
\hline Media x genotypes & 4 & $1080.93^{*}$ & 5.79 \\
\hline Hormones x media & 2 & $264.60^{*}$ & 4.48 \\
\hline Hormones x genotypes x media & 8 & $1017.44^{*}$ & 10.02 \\
\hline Sucrose & 1 & $551.83^{*}$ & 2.59 \\
\hline Sucrose x genotypes & 4 & 126.82 & $\mathrm{NS}$ \\
\hline Sucrose x hormones & 2 & 13.68 & $\mathrm{NS}$ \\
\hline Sucrose x hormones x genotypes & 8 & $318.61^{*}$ & 10.02 \\
\hline Media x sucrose & 1 & $360.58^{*}$ & 3.66 \\
\hline Media x sucrose x genotypes & 4 & $1099.01^{*}$ & 8.19 \\
\hline Hormones x media x sucrose & 2 & 29.07 & $\mathrm{NS}$ \\
\hline $\begin{array}{l}\text { Hormones x genotypes } \mathbf{x} \text { media } \\
\text { sucrose }\end{array}$ & 8 & $65.35^{*}$ & 14.18 \\
\hline Error & & & \\
\hline * Significant at P $\leq 0.05$ & 120 & 78.32 & \\
\hline
\end{tabular}


Table.4 Response of different genotypes on different media

\begin{tabular}{|l|c|c|c|c|c|c|c|}
\hline \multirow{2}{*}{ Media } & \multicolumn{7}{|c|}{ Genotypes } \\
\cline { 2 - 8 } & HPBS-1 & HPKM-04-1 & KBS-3 & HPBS-1 & $\begin{array}{l}\text { KBS-3 } \\
\text { x HPKM-04-1 }\end{array}$ & Mean & $\begin{array}{l}\text { CD } \\
(\mathbf{5} \%)\end{array}$ \\
\hline MS & 71.87 & 67.44 & 67.24 & 55.20 & 61.94 & 64.74 & 2.59 \\
& $(57.97)$ & $(55.21)$ & $(55.08)$ & $(47.99)$ & $(51.91)$ & $(53.57)$ & $($ Media) \\
\hline N $_{6}$ & 69.84 & 70.90 & 56.21 & 66.21 & 78.95 & 68.42 & \\
& $(56.69)$ & $(57.35)$ & $(48.57)$ & $(54.46)$ & $(62.69)$ & $(55.81)$ & \\
\hline Mean & 70.85 & 69.17 & 61.72 & 60.71 & 70.44 & & \\
& $(57.32)$ & $(56.27)$ & $(51.78)$ & $(51.18)$ & $(57.07)$ & & \\
\hline
\end{tabular}

$\mathrm{CD}(5 \%)=4.09$ (Genotypes)

$\mathrm{CD}$ interaction $=6.56$ (Media $\mathrm{x}$ genotypes)

Values in parentheses are arc sine transformed values

Table.5 Response of genotypes on different hormones and their combination

\begin{tabular}{|c|c|c|c|c|c|c|c|}
\hline \multirow{2}{*}{$\begin{array}{l}\text { Hormonal } \\
\text { Combinatio } \\
\text { n }\end{array}$} & \multicolumn{7}{|c|}{ Genotypes } \\
\hline & $\begin{array}{l}\text { HPBS- } \\
1\end{array}$ & $\begin{array}{l}\text { HPKM- } \\
\text { 04-1 }\end{array}$ & KBS-3 & $\begin{array}{l}\text { HPBS-1 } x \\
\text { HPKM-04-1 }\end{array}$ & $\begin{array}{l}\text { KBS-3 x } \\
\text { HPKM-04-1 }\end{array}$ & Mean & $\begin{array}{l}\text { CD } \\
(5 \%)\end{array}$ \\
\hline $\mathbf{H M}_{1}$ & $\begin{array}{l}68.62 \\
(55.93)\end{array}$ & $\begin{array}{l}62.41 \\
(52.18)\end{array}$ & $\begin{array}{l}62.16 \\
(52.03)\end{array}$ & $\begin{array}{l}40.25 \\
(39.38)\end{array}$ & $\begin{array}{l}78.00 \\
(62.03)\end{array}$ & $\begin{array}{l}62.29 \\
(52.11)\end{array}$ & $\begin{array}{l}3.17 \\
\text { (Hormones) }\end{array}$ \\
\hline $\mathrm{HM}_{2}$ & $\begin{array}{l}78.02 \\
(62.04)\end{array}$ & $\begin{array}{l}78.43 \\
(62.33)\end{array}$ & $\begin{array}{l}59.69 \\
(50.58)\end{array}$ & $\begin{array}{l}71.64 \\
(57.82)\end{array}$ & $\begin{array}{l}65.75 \\
(54.18)\end{array}$ & $\begin{array}{l}70.71 \\
(57.23)\end{array}$ & \\
\hline $\mathrm{HM}_{3}$ & $\begin{array}{l}65.92 \\
(54.28)\end{array}$ & $\begin{array}{l}66.67 \\
(54.74)\end{array}$ & $\begin{array}{l}63.33 \\
(52.73)\end{array}$ & $\begin{array}{l}70.23 \\
(56.93)\end{array}$ & $\begin{array}{l}66.46 \\
(54.61)\end{array}$ & $\begin{array}{l}66.52 \\
(54.65)\end{array}$ & \\
\hline Mean & $\begin{array}{l}70.85 \\
(57.32)\end{array}$ & $\begin{array}{l}69.17 \\
(56.27)\end{array}$ & $\begin{array}{l}61.72 \\
(51.78)\end{array}$ & $\begin{array}{l}60.71 \\
(51.18)\end{array}$ & $\begin{array}{l}70.44 \\
(57.07)\end{array}$ & & \\
\hline
\end{tabular}

$\mathrm{CD}(5 \%)=4.09$ (Genotypes)

$\mathrm{CD}$ interaction $=7.09$ (Genotypes $\mathrm{x}$ hormone)

Values in parentheses are arc sine transformed values

Table.6 Response of genotypes on different sucrose concentrations

\begin{tabular}{|c|c|c|c|c|c|c|c|}
\hline \multirow{2}{*}{ Sucrose } & \multicolumn{7}{|c|}{ Genotypes } \\
\cline { 2 - 8 } & HPBS-1 & HPKM-04- & KBS-3 & $\begin{array}{c}\text { HPBS-1 x } \\
\text { HPKM-04-1 }\end{array}$ & $\begin{array}{c}\text { KBS-3 x HPKM- } \\
\mathbf{0 4 - 1}\end{array}$ & Mean & $\begin{array}{c}\text { CD } \\
(\mathbf{5} \%)\end{array}$ \\
\hline \multirow{3}{*}{$\%$} & 74.57 & 72.09 & 60.53 & 62.65 & 71.82 & 68.33 & 2.59 \\
& $(59.72)$ & $(58.11)$ & $(51.08)$ & $(52.33)$ & $(57.93)$ & $(55.75)$ & $($ Sucrose) \\
\hline $\mathbf{4 \%}$ & 67.14 & 66.25 & 62.92 & 58.76 & 69.07 & 64.83 & \\
& $(55.02)$ & $(54.48)$ & $(52.49)$ & $(50.05)$ & $(56.21)$ & $(53.63)$ & \\
\hline Mean & 70.85 & 69.17 & 61.72 & 60.71 & 70.44 & & \\
& $(57.32)$ & $(56.27)$ & $(51.78)$ & $(51.18)$ & $(57.07)$ & & \\
& & & & & & & \\
\hline
\end{tabular}

$\mathrm{CD}(5 \%)=4.09$ (Genotypes)

CD interaction $=$ NS (Sucrose $\mathrm{x}$ genotypes)

Values in parentheses are arc sine transformed values 
Table.7 Effects of sucrose and hormones on callus induction frequency

\begin{tabular}{|c|c|c|c|c|c|}
\hline \multirow[t]{2}{*}{ Sucrose } & \multicolumn{5}{|c|}{ Hormonal combination } \\
\hline & $\mathrm{HM}_{1}$ & $\mathbf{H M}_{2}$ & $\mathrm{HM}_{3}$ & Mean & $\begin{array}{l}\text { CD } \\
(5 \%)\end{array}$ \\
\hline $3 \%$ & $\begin{array}{l}64.48 \\
(53.42)\end{array}$ & $\begin{array}{l}71.91 \\
(57.99)\end{array}$ & $\begin{array}{l}68.60 \\
(55.92)\end{array}$ & $\begin{array}{l}68.33 \\
(55.75)\end{array}$ & \multirow[t]{3}{*}{$\begin{array}{l}2.59 \\
\text { (Sucrose) }\end{array}$} \\
\hline $4 \%$ & $\begin{array}{l}60.54 \\
(51.08)\end{array}$ & $\begin{array}{l}69.50 \\
(56.48)\end{array}$ & $\begin{array}{l}64.44 \\
(53.40)\end{array}$ & $\begin{array}{l}64.83 \\
(53.63)\end{array}$ & \\
\hline Mean & $\begin{array}{l}62.51 \\
(52.24)\end{array}$ & $\begin{array}{l}70.71 \\
(57.23)\end{array}$ & $\begin{array}{l}66.52 \\
(54.65)\end{array}$ & & \\
\hline
\end{tabular}

$\mathrm{CD}(5 \%)=3.17$ (Hormone)

$\mathrm{CD}$ interaction $=\mathrm{NS}$ (Hormone $\mathrm{x}$ sucrose)

Values in parentheses are arc sine transformed values

Table.8 Performance of media with different concentrations of hormones for callus induction frequency

\begin{tabular}{|c|c|c|c|c|}
\hline \multirow{2}{*}{$\begin{array}{l}\text { Hormonal } \\
\text { Combination }\end{array}$} & \multicolumn{4}{|c|}{ Callusing Media } \\
\hline & MS & $\mathbf{N}_{6}$ & Mean & $\begin{array}{c}\text { CD } \\
(5 \%)\end{array}$ \\
\hline $\mathrm{HM}_{1}$ & $\begin{array}{c}58.74 \\
(50.03)\end{array}$ & $\begin{array}{c}66.28 \\
(54.50)\end{array}$ & $\begin{array}{c}62.51 \\
(52.24)\end{array}$ & $\begin{array}{c}3.17 \\
\text { (Hormones) }\end{array}$ \\
\hline $\mathbf{H M}_{2}$ & $\begin{array}{c}68.55 \\
(55.89)\end{array}$ & $\begin{array}{c}72.86 \\
(58.60)\end{array}$ & $\begin{array}{c}70.71 \\
(57.23)\end{array}$ & \\
\hline $\mathbf{H M}_{3}$ & $\begin{array}{c}66.92 \\
(54.89)\end{array}$ & $\begin{array}{c}66.12 \\
(54.41)\end{array}$ & $\begin{array}{c}66.52 \\
(54.65)\end{array}$ & \\
\hline Mean & $\begin{array}{c}64.74 \\
(53.57)\end{array}$ & $\begin{array}{c}68.42 \\
(55.81)\end{array}$ & & \\
\hline
\end{tabular}

Table.9 Performance of media with different sucrose concentrations for callus induction frequency

\begin{tabular}{|l|c|c|c|c|}
\hline \multirow{2}{*}{ Media } & \multicolumn{4}{|c|}{ Sucrose concentration } \\
\cline { 2 - 4 } & $\mathbf{3 \%}$ & $\mathbf{4 \%}$ & Mean & $\begin{array}{c}\text { CD } \\
\text { MS }\end{array}$ \\
\hline MS
\end{tabular}

$\mathrm{CD}(5 \%)=2.59$ (Sucrose)

$\mathrm{CD}$ interaction $=3.66$ (Media $\mathrm{x}$ sucrose)

Values in parentheses are arc sine transformed values 
Fig.1 Callus formation of genotype HPBS-1 at $\mathrm{N}_{6}$ medium
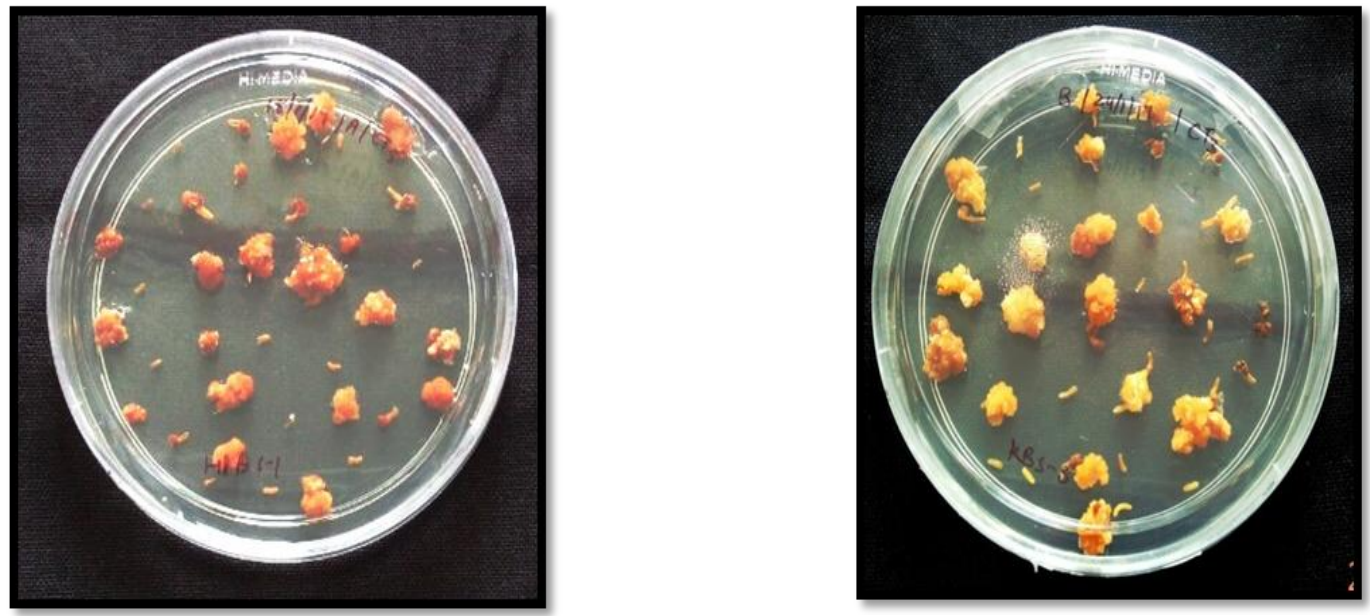

Fig.2 Response of genotype HPBS-1 with $\mathrm{HM}_{2}$ [2,4-D(0.5 mg/l) + NAA (1.0 mg/l)]
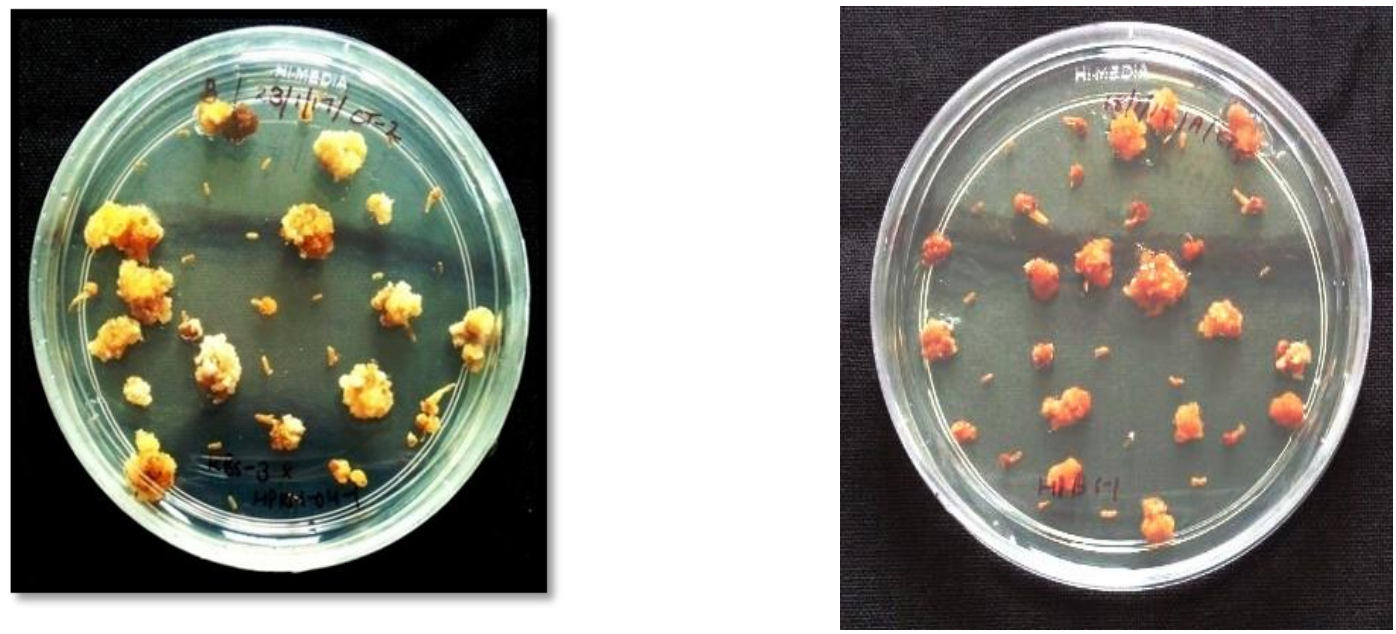

Fig.3 Effect of $3 \%$ sucrose on genotype HPBS-1
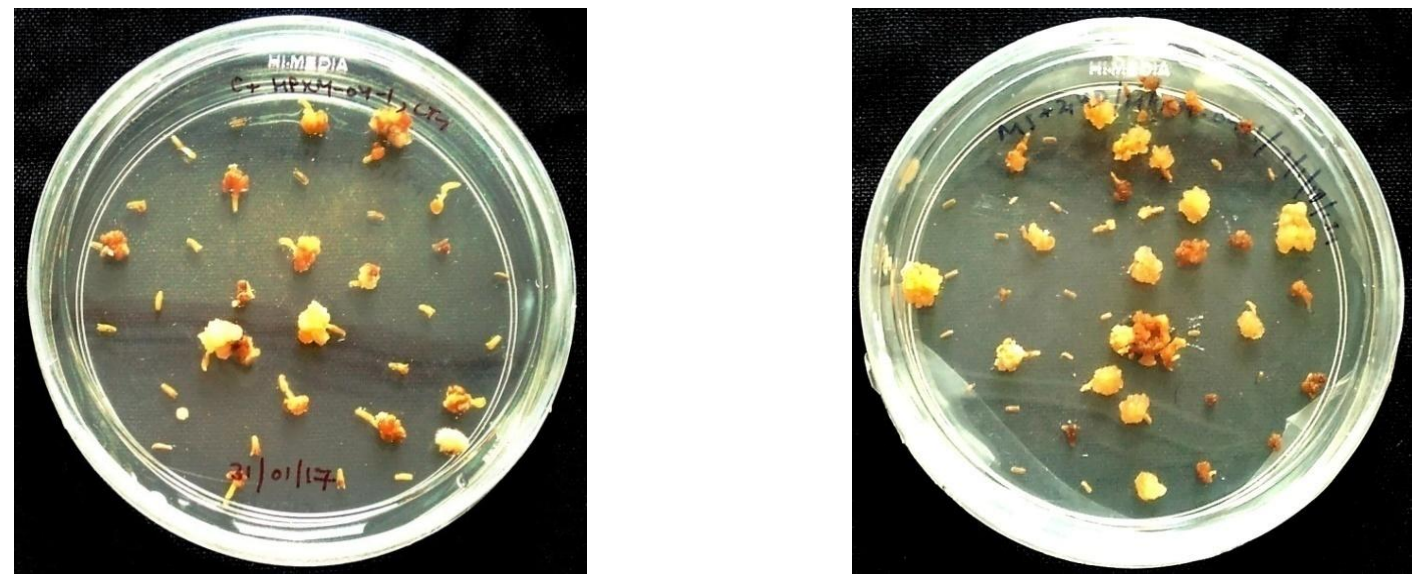
Hence concluded, in androgenesis-mediated response, the highest callusing was observed in $\mathrm{N}_{6}$ medium with $\mathrm{HM}_{2}[0.5 \mathrm{mg} / \mathrm{l} 2,4-\mathrm{D}+$ $1.0 \mathrm{mg} / \mathrm{l} \mathrm{NAA}]$ and 3 per cent sucrose. Overall, genotype HPBS-1 was the most promising for callus induction through anther culture. This media and hormonal combination can be successfully utilized for induction of haploids and double haploids in future.

\section{Acknowledgement}

A special thanks to CSK HP KV Palampur University for conducting research. I would also like to show our gratitude to my advisor Dr. Vedna Kumari and Head Dr.H.K Chaudhary for providing guidance and requisite facilities of tissue culture laboratory.

\section{References}

Alam, M.A., Haque M.A., Hossain M.R., Sarker S.C. and Afroz R, 2009. Haploid plantlet regeneration through anther culture in oilseed Brassica species. Bangladesh J. Agric. Res. 34, 698-703.

Chu, C.C., 1978. The $\mathrm{N}_{6}$ medium and its application to anther culture of cereal crops, In: Proceedings of symposium on Plant Tissue Culture, Pp. 45-50.

Guha, S., and Maheshwari S.C., 1964. In vitro production of embryos from anther culture of Datura, Nature, 2, 404-497.

Gupta S.K. and Pratap A., 2007. History, Origin and Evolution in oilseed Brassicas. Adv. Bio. Res. 45, 2-17.

Khan, M.M.A., Hassan L., Ahmad S.D., Shah A.H. and Batool F., 2009, In vitro regeneration potentiality of oilseed Brassica genotypes with differential BAP concentration. Pak. J. Bot., 41, 1233-1239.

Kumari, A., 2010. Genetic analysis of seed yield traits and response to anther culture in Indian mustard [Brassica juncea (L.) Czern. \& Coss.]. M.Sc. Thesis, p 165. Department of Crop Improvement, CSK Himachal Pradesh Krishi Vishvavidyalaya, Palampur, India.

Lone, J.A., Gupta S.K., Wani S.H., Sharma M., Lone R.A. and Shikari A.B., 2017. Efficient callus induction and regeneration in Brassica juncea for Environment friendly agriculture. Int. J. Pure Appl. Biosci. 5, 135-141

Murashige, T., and Skoog F., 1962. A revised medium for rapid growth and bioassays with tobacco cultures. Plant Physio., 15, 473-497.

Philem, S., and Chadha, S., 2010. Generation of doubled haploids through induced androgenesis in Ethiopian mustard (Brassica carinata A. Braun). J. Hill Agric. 1, 107-113.

Roy, A., and Saha P.R., 1997. Induction and plant regeneration from microspore callus in two Indian cultivars of mustard [Brassica juncea (L.) Czern and Coss]. Biologic. Sci. 63, 89-98

Sayem, M.A., Maniruzzaman; Siddique S.S., and Al-Amin M., 2010. In vitro shoot regeneration through anther culture of Brassica spp. Bangladesh J. Agri. Res. 35, 331-341.

Shekhawat, N., Jadeja G., C, Singh J., and Ramesh, 2014. Genetic diversity analysis in relation to seed yield and its component traits in Indian mustard (Brassica juncea L. Czern \& Coss). Inter. Quart. J. Lif. Sci., 9, 713-717

Shitole, A.M., 2012. Genetic analysis of seed yield and related traits in double haploid and response to anther culture in Ethiopian mustard (Brassica carinata A. Braun), M.Sc. Thesis, p 164. Department of Crop Improvement, CSK Himachal Pradesh Krishi Vishavidyalaya, Palampur, India. 
Singh, S., 2006. Androgenesis mediated generation and characterization of doubled haploids in Indian mustard [Brassica juncea (L.) Czern. and Coss.] M.Sc. Thesis, p 80. Department of Agricultural Biotechnology, CSK Himachal Pradesh Krishi Viswavidyalaya, Palampur, India.
Trivedi, N., and Dubey A., 2014. Efficient callus regeneration and multiple shoot induction in Brassica juncea var. Pusa Jaikisan. Res. J Rec. Sci. 3, 16-19

Ullah, I., Rashid H. and Khan M.R., 2004. Establishment of tissue culture protocol in Brassica (B.napus L.) Pak. J. Bio. Sci., 7, 277-278.

\section{How to cite this article:}

Sheetal Sood and Vedna Kumari. 2019. Efficient Callus Induction through Anther Culture in Cultivars of Brassica campestris var. Brown Sarson. Int.J.Curr.Microbiol.App.Sci. 8(05): 1003-1012. doi: https://doi.org/10.20546/ijcmas.2019.805.118 